\title{
O CAPITAL DE MARX SOB A PERSPECTIVA DO COLAPSO AMBIENTAL: DO FETICHISMO DA MERCADORIA À RUPTURA METABÓLICA
}

\author{
EL CAPITAL DE MARX BAJO LA PERSPECTIVA DEL COLAPSO AMBIENTAL: DEL \\ FETICHISMO DE LA MERCANCÍA A LA RUPTURA METABÓLICA
}

\section{MARX'S CAPITAL FROM THE PERSPECTIVE OF THE ENVIRONMENTAL COLLAPSE: FROM COMMODITY FETISHISM TO THE METABOLIC RIFT}

DOI: http://dx.doi.org/10.9771/gmed.v13i1.43482

\author{
Gabriel Pereira Gioppo ${ }^{1}$
}

\begin{abstract}
Resumo: Este artigo objetiva uma leitura panorâmica de $O$ capital, de Karl Marx, à luz da catástrofe ambiental contemporânea. Apoiando-se em bibliografia de teóricos ecossocialistas que realizaram uma leitura filológica e sistemática dos aspectos da obra marxiana mais relevantes dentro de uma perspectiva ecológica, percorrem-se alguns dos eixos principais de $O$ capital. De início, são explicitadas as consequências para o metabolismo social com a natureza implicadas na forma-mercadoria e no seu fetichismo. Em seguida, os desenvolvimentos que o modo de produção capitalista efetiva em sua circulação e produção (crises, aumento das forças produtivas, lei da queda tendencial da taxa de lucro, financeirização, intensificação das velocidades) são retomados em sua significância ambiental. Por fim, conclui-se o artigo apontando como, na investigação sobre a renda da terra, sob a influência de Liebig, Marx conceitualiza o colapso ambiental gerado pelo modo de produção capitalista a partir da noção de ruptura metabólica -contraposta por Marx a um modelo de sociedade futura que busque ativamente a preservação e a melhora da natureza para as gerações futuras.
\end{abstract}

Palavras-chave: Marx. Capital. Natureza. Ecologia. Metabolismo.

Resumen: Este trabajo objetiva una lectura panorámica de El Capital, de Karl Marx, a la luz de la catástrofe ambiental contemporánea. Apoyándose en bibliografía de teóricos ecosocialistas que realizaron una lectura filológica y sistemática de los aspectos de la obra marxiana más relevantes dentro una perspectiva ecológica, se traslada por algunos de los ejes principales de El Capital. En principio, son explicitadas las consecuencias para el metabolismo social con la naturaleza implicadas en la forma-mercancía y en su fetichismo. En seguida, los desarrollos que el modo de producción capitalista efectiva en su circulación y producción (crisis, aumento de las fuerzas productivas, ley de la baja tendencial de la tasa de ganancia, financierización, intensificación de las velocidades) son retomados en su significancia ambiental. Por fin, se concluye el trabajo apuntando cómo, en la investigación sobre la renta de tierra, bajo la influencia de Liebig, Marx conceptualiza el colapso ambiental generado por el modo de producción capitalista a partir de la noción de ruptura metabólica - contrapuesta por Marx a un modelo de sociedad futura que busque activamente la preservación y la mejora de la naturaleza para las generaciones futuras.

Palabras clave: Marx. Capital. Naturaleza. Ecología. Metabolismo.

Abstract: This article intends a panoramic reading of Karl Marx's Capital under the light of the contemporary environmental catastrophe. Relying on works written by ecossocialists theoreticians who performed a filological and systematic reading of the most relevant, from an ecological point of view, aspects of the marxian oeuvre, some of the main axes of Capital are covered. From the start, the consequences implied in the commodity form and its fetishism for the social metabolism are made explicit. Then, the developments carried out by the capitalist mode of production in its production and circulation (crises, increase of productive forces, tendency of the rate of profit to fall, financialization, intensification of velocities) are revisited in their environmental meaningfulness. Lastly, the article is concluded by pointing out how Marx, under Liebig's influence in the investigation of the ground rent, conceptualizes 
the environmental collapse generated by the capitalist mode of production based on the notion of metabolic rift opposed by Marx through a model of the future society that seeks to actively preserve and improve nature for the future generations.

Keywords: Marx. Capital. Nature. Ecology. Metabolism.

\section{Marx e a crise ecológica contemporânea}

O plano de fundo deste trabalho é o que se pode designar como colapso ecológico do conjunto da biosfera por ação antropogênica - o macrofenômeno denominado pelas ciências físicas e naturais de Antropoceno, no qual a ação humana sobre os ciclos biogeofísicos do planeta Terra assume a potência de forças naturais geológicas em suas capacidades transformativas e destrutivas. Compartilha-se e se pressupõe, para tudo o que será dito em seguida, das conclusões que Luiz Marques chega em Capitalismo e colapso ambiental (2018): a insustentabilidade da relação predatória que o capitalismo impõe com o conjunto dos processos naturais do planeta levará, num horizonte de menos de um século, a um crise sistêmica dos diversos ciclos que compõem a biosfera, efetivando, caso não haja uma mudança radical na maneira como vivemos em sociedade e nos concebemos como espécie, na extinção em massa das formas de vida do planeta e, dentre elas, o próprio Homo sapiens. Marques (2018, pp. 66-72) sustenta essa perspectiva a partir das seguintes proposições: (i) a da insustentabilidade do mecanismo de acumulação do capitalismo em termos ambientais, sendo ilusória e extravagante a possibilidade de educá-lo politicamente para tal fim; e como condição de possibilidade de (i), duas teses a ela complementares, "enraizadas na história europeia, matriz das sociedades hegemônicas contemporâneas": (ii) a fórmula que simboliza a promessa da economia burguesa, "mais excedente = mais segurança" torna-se, numa dialética catastrófica, "mais excedente $=$ menos segurança", e (iii) a ilusão antropocêntrica, metafísica, religiosa e filosófica, que propugna a excepcionalidade da espécie humana diante do restante da natureza, que se torna mero meio para fins humanos industriais e de dominação.

Desde a década de 60, ao menos no Ocidente, as preocupações ecológicas ocupam uma parcela crescente das discussões teóricas nos mais diversos ramos das ciências naturais e humanas. Contudo, uma leitura que permanece difundida, quase como um ponto de comum acordo nas mais diversas teorizações sobre a problemática ambiental, é a de que a obra de Karl Marx não teria contribuições relevantes a fornecer para este debate. Nessa visão, a crítica da economia política de Marx e sua tradução prática, a instauração revolucionária da sociedade comunista (ambas atravessadas por um produtivismo cego e triunfante, signo maior da bybris do homem moderno e esclarecido), seriam fundadas no crescimento exponencial das forças produtivas que, por sua própria inevitabilidade histórica, criariam uma sociedade da abundância ao mesmo tempo que superariam automaticamente a exploração capitalista. Em suma, um Marx prometeísta - designação que remete à figura mitológica grega e os homens emancipadora do jugo do Olimpo através da dádiva do fogo².

Contudo, outros teóricos da crise ecológica ressaltam a necessidade de se pensar Marx para além das suas figurações produtivistas. De especial relevância para este trabalho é a segunda geração dos 
teóricos ecossocialistas - sobretudo autores como John Bellamy Foster (2000), Paul Burkett (1999) e Kohei Saito (2017) -, que lavrou uma leitura historicamente contextualizada e filologicamente apoiada nos mais recentes cadernos da MEGA-2 para mostrar o caráter sistemático de reflexões marxianas que são lidas hoje como ecológicas. A partir destas fontes, este artigo objetiva mostrar que o materialismo histórico e a crítica da economia política de Marx têm algo a dizer sobre a relação infernal entre capitalismo e colapso ambiental. A análise será panorâmica: não sendo possível uma análise das obras de juventude ${ }^{3}$, realizar-seá um comentário dos pontos de maior relevância, dentro de uma perspectiva ambiental, em $O$ capital, que será abundantemente citado. Desse modo, as teorias do trabalho como metabolismo, do fetichismo da mercadoria, da acumulação capitalista e da renda da terra serão utilizadas para mostrar as possíveis contribuições que Marx pode oferecer à inteligibilidade da problemática ecológico-social que aflige o presente e ameaça o futuro não apenas das sociedades humanas organizadas, mas também das espécies da Terra.

\section{Fetichismo da mercadoria como matriz da cegueira ecológica capitalista}

A conceitualização teórica da concepção materialista da história e da natureza que Marx desenvolve juntamente com Engels em $A$ ideologia alemã, de 1845-6, é intimamente conectada com uma filosofia crítica e da práxis, que almeja a transformação radical do modo de organização da produção da vida social através da ação revolucionária da classe trabalhadora. É nesta perspectiva que o materialismo histórico enquanto coordenada filosófica se desdobra em uma crítica da economia politica, projeto que ocupará Marx até o fim de sua vida, restando inconcluso. Diversas foram as suas formulações estruturais ${ }^{4}$, a começar pelos esboços dos Manuscritos de 1844, passando pela primeira sistematização encontrada em 1857-1858 nos Grundrisse, até chegar aos três livros de O capital - o primeiro, publicado em 1967, o segundo e o terceiro editados por Engels postumamente e publicados em 1885 e 1894; os manuscritos de Marx que serviram de base ao livro III são principalmente da década de 60, os do livro II, sobretudo da década de 70. Marx (2013, p. 79) escreve, no prefácio à primeira edição do livro I, que "a finalidade última desta obra é desvelar a lei econômica do movimento da sociedade moderna", um desvelamento que objetiva "abreviar e mitigar as dores do parto" de uma nova sociedade surgida a partir das condições históricas propiciadas pelo modo de produção capitalista. Este revolucionário objetivo já servia como orientação primordial do pensamento de Marx desde 1845, mas, se ele é exposto neste trabalho somente a partir da década de 60 , é pelo fato de ser aqui que ele ganha maior desenvoltura, alcance e coerência interna, ou seja, que vai mais fundo na capacidade explicativa dos fenômenos e movimentos fundamentais da sociedade capitalista.

Na Introdução de 1857 dos Grundrisse (2011, pp. 39-64) Marx, em plena consonância com as suas investigações da década de 40, explica os pressupostos basilares da crítica da economia política. Contra as "robinsonadas" da economia política burguesa, Marx concebe o indivíduo - enquanto existência material, corporal, pulsional, muscular etc. - em sua relação intrínseca com a sociedade: a produção material explica-se pelos "Indivíduos produzindo em sociedade" (MARX, 2011, p. 39) - por isso, o ponto de 
partida é, naturalmente, a produção socialmente determinada. Toda sociedade devém historicamente; portanto, a produção material-social é, ao mesmo tempo, historicamente condicionada; é fruto de um processo temporal em que cada geração, conforme às condições que a história anterior lhe legou, produz suas formas de vida. Mas toda produção material pressupõe um intercâmbio com aquilo que é exterior à existência corporal do indivíduo socialmente determinado; exige-se, pois, uma relação intrínseca com a natureza: "Toda produção é produção da natureza pelo indivíduo no interior de e mediada por uma determinada forma de sociedade" (MARX, 2011, p. 41). Marx diz algo que pode parecer trivial, mas cujas reverberações serão sentidas em todo o seu sistema, a saber, que o pressuposto de toda a crítica da economia política é a categoria de produção, uma categoria inconcebível sem as suas mediações sociais e naturais.

Na mesma Introdução, Marx reconduz as operações econômicas da distribuição, da troca e do consumo enquanto momentos de um processo de produção que thes condiciona e é por elas reciprocamente condicionado (pois a noção de 'determinação' em Marx é dialética e não mecânica-causal, exprime uma interdependência recíproca e coprodutiva entre categorias relacionais e não-idênticas):

O resultado a que chegamos não é que produção, distribuição, troca e consumo são idênticos, mas que todos eles são membros de uma totalidade, diferenças dentro de uma unidade. A produção estende-se tanto para além de si mesma na determinação antitética da produção, como sobrepõe-se sobre os outros momentos. É a partir dela que o processo sempre recomeça. (...) Uma produção determinada, portanto, determina um consumo, uma troca e uma distribuição determinados, bem como relações determinadas desses diferentes momentos entre si. A produção, por sua vez, certamente é também determinada, em sua forma unilateral, pelos outros momentos. (...) Há uma interação entre os diferentes momentos. Esse é o caso de qualquer todo orgânico (MARX, 2011, p. 53).

Nada mais distante de uma mera causalidade mecânica ou de um determinismo simplista; em Marx, efetua-se um pensamento das mútuas interações sistêmicas dentro de um todo orgânico em movimento, um esforço de conceitualização, uma passagem do abstrato ao concreto no pensamento, para dar conta da totalidade material-social-natural e processual em seus diversos momentos e relações. Se, o concreto "é a síntese de múltiplas determinações, portanto, unidade da diversidade" que aparece "no pensamento como processo da síntese, como resultado, (...) não obstante seja o ponto de partida efetivo”, então "o método de ascender do abstrato ao concreto é somente o modo do pensamento de apropriar-se do concreto, de reproduzi-lo como um concreto mental". Porém, Marx assevera que o processo de apreensão, pela força do pensamento, dos movimentos concretos das formas sociais "de forma alguma é o processo de gênese do próprio concreto" (MARX, 2011, pp. 54-55).

A noção de produção é, em $O$ capital, descrita dentro de dois processos não-idênticos e, contudo, intimamente conectados em razão da forma social que recobre esta produção sob o capitalismo (ou, ainda, em razão das relações de produção capitalistas). São eles: o processo de trabalho e o processo de valorização. Marx (2013, p. 255) define o trabalho como "um processo entre o homem e a natureza, processo este em que o homem, por sua própria ação, medeia, regula e controla seu metabolismo com a 
natureza". Todo metabolismo, como a palavra alemã Stoffwechsel indica, é um processo de intercâmbio material5. Enquanto matéria, nervos, músculos, cérebro, ossos, o ser humano, diz Marx,

\begin{abstract}
se confronta com a matéria natural como uma potência natural. A fim de se apropriar da matéria natural de uma forma útil para sua própria vida, ele põe em movimento as forças naturais pertencentes a sua corporeidade: seus braços e pernas, cabeça e mãos. Agindo sobre a natureza externa e modificando-a por meio desse movimento, ele modifica, ao mesmo tempo, sua própria natureza. Ele desenvolve as potências que nela jazem latentes e submete o jogo de suas forças ao seu próprio domínio. (MARX, 2013, p. 255)
\end{abstract}

$\mathrm{Na}$ condição de metabolismo com a natureza (a matéria-prima, condição objetiva universal da produção), o trabalho é também - e fundamentalmente - uma atividade orientada a um fim conscientemente estabelecido pela consciência humana. Através da posição de uma representação que serve como guia, o trabalho é realizado por meio de um intercâmbio material do corpo humano com a natureza - assim, ele atinge patamares de transformação da matéria natural inalcançáveis pela mera ação instintiva dos animais. Por fim, os últimos componentes do processo de trabalho são suas condições objetivas de efetivação: os instrumentos e meios de produção a partir dos quais o ser humano, este toolmaking animal, realiza uma atividade conscientemente posta que se objetiva no intercâmbio material com a natureza (MARX, 2013, p. 255-257).

O resultado final de todo trabalho, evidentemente, é um produto. Há em todo produto uma propriedade específica, ligada ao processo de trabalho pelo qual ele veio a ser: ele possui um valor de uso, uma capacidade de servir à satisfação de necessidades humanas em razão de suas qualidades concretas, materiais, úteis; estas necessidades, por sua vez, são praticamente infinitas em suas modalidades, podendo um produto qualquer ser reutilizado e novamente transformado em novos processos de trabalho ou ser consumido de maneira individual, coletiva etc. É o trabalho que vivifica produtos anteriores do trabalho humano coletivo, que os reapropria em função de novas transformações qualitativas na própria natureza e que, através de sua efetivação, conserva valores já existentes ${ }^{6}$.

Marx, em consonância com a premissa metodológica de uma passagem do abstrato ao concreto, resume a exposição do trabalho "em seus momentos simples e abstratos" como

a atividade orientada a um fim - a produção de valores de uso -, apropriação do elemento natural para a satisfação de necessidades humanas, condição universal do metabolismo entre homem e natureza, perpétua condição natural da vida humana e, por conseguinte, independente de qualquer forma particular dessa vida, ou melhor, comum a todas as suas formas sociais. (MARX, 2013, p. 261)

A exposição até aqui feita é abstrata porque desconsidera a especificidade social de cada modo de producão, ignora seu processo histórico de vir a ser, isto é, a maneira historicamente condicionada de como cada sociedade regula coletivamente o seu metabolismo com a natureza. Não há trabalho, intercâmbio material com a natureza para produção de valores de uso, concebível sem sociedade, não há sociedade sem história; não há, portanto, trabalho que não tenha especificidade sócio-histórica, que não se realize na prática materialsocietal de diferentes períodos, que produza valores de uso para a satisfação das mais variadas satisfações humanas. 
O que diferencia o modo de produção capitalista das demais organizações sócio-históricas de produção que lhe antecederam é a forma que o produto recebe, a forma-mercadoria, graças ao processo de produção especificamente capitalista que lhe deu corpo, sentido e finalidade. A mercadoria é, então, a forma determinada do produto no capitalismo, a forma pela qual se regula o intercâmbio material entre sociedade e natureza neste modo de produção:

A riqueza das sociedades onde reina o modo de produção capitalista aparece como uma 'enorme coleção de mercadorias', e a mercadoria individual, por sua vez, aparece como sua forma elementar. (MARX, 2013, p. 113)

Mas produzir um produto enquanto mercadoria é diferente de produzi-lo enquanto produto em geral, pois nela o "o valor de uso não é, de modo algum, a coisa qu'on aime pour lui-même. (...) [O]s valores de uso só são produzidos porque e na medida em que são o substrato material, os suportes do valor de troca" (MARX, 2013, p. 263) - o processo de trabalho devém, através dessa transformação qualitativa que subordina a matéria ao valor de troca, processo de valorização.

Logo, diversamente de toda a produção humana anterior ao capitalismo ${ }^{7}$, o que caracteriza e especifica esse modo de produção é o fato de que a produção de valores de uso (dotados de qualidades concretas e sensíveis específicas, ligadas à satisfação de necessidades reais dos indivíduos que compõem uma sociedade) é subsumida ao imperativo do valor de troca ou, simplesmente, ao valor. O capitalista, ao comprar do trabalhador expropriado dos meios de produção a sua única mercadoria disponível, a força de trabalho (a única mercadoria, lembremos, capaz de produzir valor, cuja origem está no processo de trabalho), não tem em vista imediatamente a produção de valores de uso, e sim apenas o valor de uso de uma mercadoria enquanto receptáculo material do seu valor de troca, a sua capacidade de ser trocado por outros produtos:

Primeiramente, ele quer produzir um valor de uso que tenha um valor de troca, isto é, um artigo destinado à venda, uma mercadoria. Em segundo lugar, quer produzir uma mercadoria cujo valor seja maior do que a soma do valor das mercadorias requeridas para sua produção, os meios de produção e a força de trabalho, para cuja compra ele adiantou seu dinheiro no mercado. Ele quer produzir não só um valor de uso, mas uma mercadoria; não só valor de uso, mas valor, e não só valor, mas também mais-valor. (MARX, 2013, p. 263)

O valor de troca de uma mercadoria (reiterando, uma forma social do produto predominante apenas no modo de produção capitalista), ou simplesmente seu valor, é a sua determinação não qualitativa, não concreta, não material, por conseguinte, é a sua determinação abstrata, idêntica em todos os casos e quantitativa, enquanto "dispêndio de força de trabalho" em geral. Logo, sua medida é o "tempo de trabalho socialmente necessário", que é "computado na formação do valor" (MARX, 2013, p. 266). Como consequência, o valor de um produto deixa de ser, no capitalismo, dado pela sua concretude qualitativa útil, e passa a ser determinado, segundo Marx, por uma medida abstrata e quantitativa de tempo de trabalho socialmente necessário, o tempo médio que uma sociedade dada leva para produzir uma determinada mercadoria. É uma medida ou média socialmente dada que, por isso mesmo, é impossível de ser mensurada caso a caso (de outro modo, seria preciso um relógio onisciente e onipotente em cada troca), o que postula a exigência de uma mercadoria especifica, que servirá como agente universal de todas as trocas e 
como expressão material universal do valor contido, do trabalho objetivado em cada mercadoria, para que possa ela ser trocada por outras. Fala-se, obviamente, do dinheiro, que assume diversas formas em razão de sua capacidade de servir como mediador universal nas trocas: ouro, papel, moeda; hoje em dia bitcoin, código informacional na tela do celular etc. (mas qualquer mercadoria pode servir como mediador universal da troca, demonstra Marx, e se é o ouro ou a bitcoin que o são, isto se dá pelos benefícios e facilidades que se oferecem à circulação de mercadorias e de capital em razão de suas propriedades materiais).

Ou seja, uma mercadoria que expressa seu valor no equivalente universal de todas as mercadorias, no dinheiro, expressa seu valor em preço, uma propriedade meramente social-ideal atribuída, em função das necessidades de troca, à uma mercadoria específica - material, já que o dinheiro é palpável; seu significado, porém é social e mental - que passa a servir como mediadora de todas as outras trocas. Diz Marx sobre a relação entre dinheiro e mercadoria:

As mercadorias não se tornam comensuráveis por meio do dinheiro. Ao contrário, é pelo fato de todas as mercadorias, como valores, serem trabalho humano objetivado e, assim, serem, por si mesmas, comensuráveis entre si, que elas podem medir conjuntamente seus valores na mesma mercadoria específica e, desse modo, convertê-la em sua medida comum de valor, isto é, em dinheiro. O dinheiro, como medida de valor, é a forma necessária de manifestação da medida imanente de valor das mercadorias: o tempo de trabalho. (...) O preço ou a forma-dinheiro das mercadorias, tal como sua forma de valor em geral, é distinto de sua forma corpórea real e palpável, ou seja, é forma apenas ideal ou representada. (...) A mercadoria é realmente valor de uso; seu valor se manifesta apenas idealmente no preço, que a reporta ao ouro, situado no polo oposto, como sua figura de valor real. Inversamente, o material do ouro vale apenas como materialiadade de valor, dinheiro. Ele é, por isso realmente valor de troca. Seu valor de uso aparece apenas idealmente na série das expressões relativas de valor na qual ele se relaciona com as mercadorias a ele contrapostas, como o círculo de suas figuras reais de uso. Essas formas antitéticas das mercadorias são as formas efetivas do movimento de seu processo de troca. (MARX, 2013, p. 169-170, 179)

Mas se, como indicado anteriormente, a finalidade da produção capitalista é a produção não de valores de uso, e sim de valores de troca, isto é, expressões do valor da mercadoria sob a forma-preço ou forma-dinheiro, então o conjunto das capacidades produtivas, das interações metabólicas entre seres humanos socialmente organizados e a natureza, passa a ser regulado por uma medida abstrata e quantitativa. Pior ainda, uma abstração que escapa ao controle dos indivíduos singulares e, por isso mesmo, assume o caráter mítico de uma naturalidade inescapável:

Vemos, por um lado, como a troca de mercadorias rompe as barreiras individuais e locais da troca direta de produtos e desenvolve o metabolismo do trabalho humano. Por outro, desenvolve-se um círculo completo de conexões que, embora sociais, impõem-se como naturais, não podendo ser controladas por seus agentes (MARX, 2013, p. 186).

É precisamente esse duplo movimento, ao mesmo tempo abstrativo do conteúdo concreto da produção e socialmente aceito como inevitável ou como "natural", que confere à produção de mercadorias o seu caráter mistico, denominado por Marx de fetichismo da mercadoria:

Uma mercadoria aparenta ser, à primeira vista, uma coisa óbvia, trivial. Mas sua análise a revela como uma coisa muito intricada, plena de sutilezas metafísicas e caprichos teológicos. (...) É evidente que o homem, por meio de sua atividade, altera as formas 
das matérias naturais de um modo que lhe é útil. Por exemplo, a forma da madeira é alterada quando dela se faz uma mesa. No entanto, a mesa continua sendo madeira, uma coisa sensível e banal. Mas tão logo aparece como mercadoria, ela se transforma numa coisa sensível-suprassensível. Ela não se contenta em manter os pés no chão, mas põe-se de cabeça para baixo em relação a todas as outras mercadorias, e em sua cabeça de madeira nascem minhocas que nos assombram muito mais do que se ela começasse a dançar por vontade própria (MARX, 2013, p. 146).

A causa do caráter místico da mercadoria não está em seu valor de uso, que não comporta maiores mistérios como mera qualidade concreta, sensível, que satisfaz necessidades humanas; nem está no conteúdo das determinações de valor, nos trabalhos úteis socialmente determinados que produzem tais valores de uso, pois são todos igualmente “dispêndio de cérebro, nervos, músculos e órgãos sensoriais humanos etc.” que assumem uma forma social e temporal. Prossegue Marx:

De onde surge, portanto, o caráter enigmático do produto do trabalho, assim que ele assume a forma-mercadoria? Evidentemente, ele surge dessa própria forma. (...) $\mathrm{O}$ caráter misterioso da forma-mercadoria consiste, portanto, simplesmente no fato de que ela reflete aos homens os caracteres sociais de seu próprio trabalho como caracteres objetivos dos próprios produtos do trabalho, como propriedades sociais que são naturais a essas coisas e, por isso, reflete também a relação social dos produtores com o trabalho total como uma relação social entre objetos, existente à margem dos produtores. (MARX, 2013, pp. 146-147)

A teoria do fetichismo de Marx é rica em consequências filosóficas, sociológicas, históricas e políticas, e rendeu incontáveis páginas de comentários e polêmicas desde sua publicação em 1867. Duas consequências notáveis, entrevistas no próprio texto marxiano, para uma compreensão do momento ecológico da crítica da economia política (SAITO, 2017, cap. 3), merecem um destaque. Em primeiro lugar, ela aponta um motivo fundamental da cegueira do discurso econômico apologético quanto às consequências nefastas da produção capitalista em relação à natureza e aos seres humanos, pois, como consequência da forma social que reveste os produtos-mercadoria, eles aparecem aos homens como entidades autorreferenciáveis e autossubsistentes, independentes de qualquer matéria natural, que devém seu mero receptáculo (seja ele o corpo de um trabalhador, ou a pele de um animal, ou a água de um rio). Ora, argumenta Marx:

O quanto uma parte dos economistas é enganada pelo fetichismo que se cola ao mundo das mercadorias ou pela aparência objetiva das determinações sociais do trabalho é demonstrado, entre outras coisas, pela fastidiosa e absurda disputa sobre o papel da natureza na formação do valor de troca. Como este último é uma maneira social determinada de expressar o trabalho realizado numa coisa, ele não pode conter mais matéria natural do que, por exemplo, a taxa de câmbio. (MARX, 2013, p. 157)

Uma leitura apressada sustentaria - e muitos a fizeram - que Marx defende, aqui, a indiferença quanto à natureza na formação do valor em geral. Em contrário, foi explicado acima sentido que a relação com a natureza constitui o componente fundacional do trabalho concebido enquanto intercâmbio material humano que qualitativamente transforma o mundo natural segundo finalidades dadas. Marx não poupa palavras ao explicitar essa interdependência na produção das riquezas:

Ao produzir, o homem pode apenas proceder como a própria natureza, isto é, pode apenas alterar a forma das matérias. Mais ainda: nesse próprio trabalho de formação ele é constantemente aparado pelas forças da natureza. Portanto, o trabalho não é a única fonte dos valores de uso que ele produz, a única fonte da riqueza material. Como diz 
William Petty, o trabalho é o pai, e a terra é a mãe da riqueza material. (MARX, 2013, p. 121)

Quando Marx se referiu na passagem citada anteriormente às fastidiosas disputas sobre o papel da natureza na formação do valor, ele fala, evidentemente, do valor de troca das mercadorias, que não é senão a expressão social-mistificada, sob a forma-preço ou forma-dinheiro, da materialidade concreta da produção humana na sociedade capitalista, dos valores de uso que a classe trabalhadora produz em seu metabolismo com o mundo; uma expressão que acaba por apagar a própria materialidade e o socius dos quais parte.

É essa forma mistificada, abstraída de qualquer conteúdo social ou natural e dos efeitos aí gerados, que funda o mito econômico da acumulação infinita, assim como a idolatria dos modelos e dos números, no qual a carne viva do planeta Terra é sacrificada pelos economistas e capitalistas ao seu insaciável e etéreo deus-dinheiro. Como as categorias da economia burguesa derivam do fetichismo da mercadoria, poder-se-ia pensar que o mero o desvelamento de seu caráter ilusório resolveria o problema ${ }^{8}$. Mas a imbricação do fetichismo à forma-mercadoria liga-o às relações de produção que dão forma à produção da mercadoria, garantindo-lhes objetividade e naturalidade, de modo que sua superação exige a transformação da própria maneira como a sociedade produz:

Trata-se de formas de pensamento socialmente válidas e, portanto, dotadas de objetividade para as relações de produção desse modo social de produção historicamente determinado, a produção de mercadorias. Por isso, todo o misticismo do mundo das mercadorias, toda a mágica e a assombração que anuviam os produtos do trabalho na base da produção de mercadorias desaparecem imediatamente, tão logo nos refugiemos em outras formas de produção. (MARX, 2013, p. 151)

Para Marx, assim, a superação da forma-mercadoria e do fetichismo que lhe é inerente só é possível através da práxis revolucionária, e não, como sustentaram os jovens hegelianos na década de 40, através de uma pura operação mental de desmistificação das ilusões. O papel que a crítica da economia política realiza, aqui, é o de apontar a lei fundamental de movimento da sociedade capitalista e, por meio disso, mostrar a gênese histórica das aparências socialmente necessárias que a atravessam.

Mas se "a forma-mercadoria e a relação de valor dos produtos do trabalho em que ela se representa não guardam (...) absolutamente nenhuma relação com sua natureza física e com as relações materiais" (MARX, 2013, p. 147) que dela derivam, o modo de produção capitalista realiza uma dupla torção em sua relação com a natureza. Por um lado, como explicado acima, ele assume uma naturalidade quase mítica, aparecendo como a única maneira possível de organização da produção, ou ainda, a mais natural de todas elas, ignorando qualquer cognição de um devir histórico das formações sociais. Por outro lado, ao destacar-se de toda qualidade concreta e material que implica uma relação efetiva e constitutiva com a natureza, a forma capitalista de produção funda o paradigma encantado de uma acumulação infinita em um planeta finito, um corolário da centralidade do acúmulo de capital como finalidade primordial da existência social, humana e natural. A teoria marxiana do fetichismo da mercadoria mostra, assim, a gênese da simultânea "naturalização" e "antinaturalidade" do modo de produção capitalista. Marx dá o tom catastrófico sobre qual seria o "limite" deste processo, do ponto de vista daqueles encantados por este fetichismo: 
O capital, que tem tão "boas razões" para negar os sofrimentos das gerações de trabalhadores que o circundam, é, em seu movimento prático, tão pouco condicionado pela perspectiva do apodrecimento futuro da humanidade e seu irrefreável despovoamento final quanto pela possível queda da Terra sobre o Sol. Em qualquer manobra ardilosa no mercado acionário, ninguém ignora que uma hora ou outra a tempestade chegará, mas cada um espera que o raio atinja a cabeça do próximo, depois de ele próprio ter colhido a chuva de ouro e o guardado em segurança. Après moi le déluge! é o lema de todo capitalista e de toda nação capitalista. (MARX, 2013, p. 342)

\section{Crises e acumulação em $\mathrm{O}$ capital sob um prisma ecológico.}

Nem toda acumulação de mercadoria-dinheiro, porém, constitui um capital. Marx define a fórmula geral da circulação de mercadorias como M-D-M, em que, grosso modo, uma mercadoria qualquer $\mathrm{M}$ é trocada pelo agente universal de troca, por dinheiro $\mathrm{D}$, que é utilizado, por sua vez, para comprar outra mercadoria M. Por exemplo, um alfaiate que vende seus produtos, roupas, para comprar pão. Uma variação dessa fórmula é D-M-D, na qual uma quantidade qualquer de dinheiro serve para comprar uma mercadoria, por sua vez revendida. Marx ressalta, contudo, a inocuidade, do ponto de vista capitalista, do ciclo caso D permanecesse igual: “o processo de circulação D-M-D seria absurdo e vazio se a intenção fosse realizar, percorrendo seu ciclo inteiro, a troca de um mesmo valor em dinheiro pelo mesmo valor em dinheiro" (MARX, 2013, p. 224).

A diferença de forma entre (a) M-D-M e (b) D-M-D é explicada por seu conteúdo: (a) começa com a venda e termina com a compra, seu objetivo é adquirir ao final uma mercadoria, sendo o dinheiro apenas um valor de uso (ser agente da circulação) gasto de modo definitivo; (b) começa com a compra e termina com a venda objetivando, por sua vez, de adquirir mais dinheiro. É por isso que Marx reformula (b) como D-M-D', em que D' representa, sob a forma-dinheiro, um "incremento, ou excedente sobre o valor original" denominado de mais-valor, nessa fórmula, além disso, a própria mercadoria serve como mero receptáculo material para a acumulação de mais dinheiro. Se em (a) D ainda é subordinado a M, em (b) M torna-se função no processo maior de transformação de $\mathrm{D}$ em D', na valorização de $D$, uma maneira de obter mais-valor em que o dinheiro é posto no início e no final do movimento de circulação:

Como portador consciente desse movimento, o possuidor de dinheiro se torna capitalista. (...) O conteúdo objetivo daquela circulação - a valorização do valor - é a sua finalidade subjetiva, e é somente enquanto a apropriação crescente da riqueza abstrata é o único motivo de suas operações que ele funciona como capitalista ou capital personificado, dotado de vontade e consciência. Assim, o valor de uso jamais pode ser considerado como finalidade imediata do capitalista. Tampouco pode sê-lo o lucro isolado, mas apenas o incessante movimento do lucro. (MARX, 2013, p. 229)

Marx diz aqui algo que está em plena continuidade lógica com a teoria do fetichismo da mercadoria: a fórmula geral de circulação do capital, que é personificada nos capitalistas, começa e termina com o dinheiro D, ela utiliza das mercadorias $M$ como suporte, indiferente em relação às suas determinações materiais e naturais, para sua finalidade última, a saber, a incessante obtenção de mais-valor, expresso na forma-preço como lucro. "O valor se torna, assim, valor em processo, dinheiro em processo e, como tal, capital" (MARX, 2013, p. 231). 
Como troca de equivalentes, é natural que na fórmula D-M-D' “cada uma das partes não extrai da circulação mais valor do que nela lançou inicialmente. Não há, então, criação de mais-valor" (MARX, 2013, p. 235). Ainda que sejam vendidas mercadorias M acima ou abaixo de seu valor através do aumento ou diminuição do preço de cada uma delas- o que permitirá a comerciantes mais astuciosos abocanhar uma fatia maior do valor total produzido na sociedade, em razão da diferença flutuante entre valor e preço - resta que a própria fórmula D-M-D’ não explica como se cria o mais-valor e, portanto, não explica a transformação do dinheiro em capital. Não basta, pois, ser um bom comerciante para ser capitalista. Essa transformação exige que se compre uma mercadoria (D-M) “cujo próprio valor de uso possuísse a característica peculiar de ser fonte de valor, cujo próprio consumo fosse, portanto, objetivação de trabalho e, por conseguinte, criação de valor" (MARX, 2013, p. 242). Ora, vimos que a única potência natural capaz de criar valor é, na crítica da economia política marxiana, a força de trabalho humana, vendida pelo trabalhador ao capitalista. Por força de trabalho, então, Marx entende "o complexo das capacidades físicas e mentais que existem na corporeidade, na personalidade viva de um homem e que ele põe em movimento sempre que produz valores de uso de qualquer tipo" (MARX, 2013, p. 242); seu valor é idêntico ao valor dos meios de subsistência necessários ao trabalhador em um determinado período e sociedade.

Marx elenca uma série de outros requisitos do processo de produção capitalista - são os "pressupostos históricos" do capital: (i) um capitalista que conscientemente aplica seu dinheiro como capital, buscando valorizá-lo; (ii) a compra de uma mercadoria específica, a força de trabalho, única capaz de no processo de produção gerar mais-valor; (iii) que essa força de trabalho seja livremente vendida no mercado por seu possuidor, o trabalhador; (iv) que haja uma separação entre o produtor e seus meios de produção, que devêm propriedade do capitalista - que o trabalhador seja, portanto, expropriado de seus meios de produção e seu produto alienado; (v) que o trabalhador receba um salário como pagamento pelo valor de uso de sua força de trabalho no processo de produção; e (vi) que o valor pago pelo uso da força de trabalho seja menor que o valor total produzido durante o processo, caso contrário, não haveria criação de mais-valor e todo o movimento perderia, para o capitalista, seu sentido ${ }^{9}$. A criação de valores (e de maisvalor) só é explicável em um movimento conceitual que analise o conjunto dos processos capitalistas, tanto as duas fases da circulação como o processo de produção do capital, envolvendo o metabolismo da força de trabalho com a natureza mediado pelos meios de produção; um esforço conceitual que não se atenha, portanto, como o fez a economia política clássica - e suas aporias são evidência disso - à mera circulação formal de mercadorias. Um deslocamento analítico do mercado enquanto espaço formal de trocas à produção enquanto momento fundamental do metabolismo social da naturez̧a é a única condição para a explicação da gênese do valor.

A fórmula analítica a que Marx chega para descrever o conjunto ou a unidade dialética dos movimentos de circulação e produção do capital é complexa, ocupando em seus desdobramentos toda a primeira seção do livro II de O capital (MARX, 2014, pp. 107-200). O capital, enquanto forma social dada a um movimento material de pessoas, mercadorias e recursos é um processo cuja finalidade principal encontra-se na valorização. Ele assume, em primeiro lugar, a forma de capital-monetário, aquele capital que, na esfera da circulação sob a forma-dinheiro, tem como função adquirir as mercadorias essenciais para o 
processo de produção: a força de trabalho, os meios de produção, as matérias-primas etc. Quando a força de trabalho empregada pelo capital vivifica os meios de produção e as matérias-primas durante o processo de trabalho, cria-se mais valor - o capital, aqui, não está mais na esfera da circulação, mas nas manufaturas, nas fábricas e industrial, é o capital produtivo. Por fim, retira-se do processo de produção uma mercadoria valorizada, cujo valor de saída representa, em razão da ação da força de trabalho, uma quantidade maior em relação ao início do processo de produção: o capital se torna capital-mercadoria, assume a forma-mercadoria que deve ser vendida novamente na esfera da circulação para realizar o valor e o mais-valor nelas contido. Logo, o capital é um movimento ou processo cíclico de valorização através da produção de mercadorias pela apropriação em escalas progressivamente maiores das forças e matérias naturais (força de trabalho, meios de produção, matérias-primas) que possui três metamorfoses: o capitalmonetário (primeira etapa da esfera da circulação, condição de possibilidade da produção), o capital-produtivo (etapa localizada na esfera da produção, somente onde se pode criar valor através do intercâmbio material com a natureza mediado pela forma capitalista) e o capital-mercadoria (cuja venda realiza o mais-valor contido nas mercadorias sob a forma dinheiro e permite reiniciar todo o ciclo).

A partir das metamorfoses cíclicas do capital, pode-se compreender alguns aspectos maiores do movimento de produção e circulação de mercadorias dentro das sociedades capitalistas contemporâneas, assim como de suas tendências materiais a curto, médio e longo prazo. É principalmente do ponto de vista dos efeitos sobre a classe trabalhadora que Marx analisa estas tendências estruturais, firmemente fincadas no descolamento, operado pelo capital, da finalidade da produção em relação à sua própria concretude material. O privilégio dado aos efeitos sobre a classe trabalhadora, porém, não excluirá de maneira alguma o tratamento de questões ambientais. Mencionemos resumidamente de algumas destas tendências.

Se o excedente de valor (ou mais-valor) que dá sentido ao movimento produtivo capitalista só é possível quando o valor atingido ao final do processo é maior do que aquele da força de trabalho e dos meios de produção consumidos, então duas tendências emergem deste fato. Em primeiro lugar, uma tendência ao aumento extensivo da jornada de trabalho para fins de obtenção do mais-valor absoluto, já que o tempo de trabalho socialmente necessário para a reprodução da força de trabalho - o valor dos meios de subsistência - é ultrapassado em uma determinada hora $\mathrm{x}$ do processo produtivo diário, redundando o restante do tempo que o trabalhador utiliza sua força de trabalho, e o valor aí gerado, em lucro para o capitalista. Evidentemente, este é um lucro que aniquila em poucos anos os trabalhadores submetidos a jornadas progressivamente maiores, uma lógica destrutiva que, para Marx, é idêntica àquela que arrasa os recursos naturais:

O capital não se importa com a duração de vida da força de trabalho. O que lhe interessa é única e exclusivamente o máximo de força de trabalho que pode ser posta em movimento numa jornada de trabalho. Ele atinge esse objetivo por meio do encurtamento da duração da força de trabalho, como um agricultor ganancioso que obtém uma maior produtividade da terra roubando dela sua fertilidade. (MARX, 2013, p. 338)

Uma segunda tendência é descrita por Marx (2013, seção IV) a partir da noção de mais-valor relativo. Em vista da limitação natural ou legal de aumento extensivo da extração de mais-valor (a partir do 
momento em que a pressão política organizada da classe trabalhadora leva à criação de legislações que limitem as horas de trabalho diárias), o capital efetua um movimento de aumento da produtividade. Aumentando a produtividade, aumenta-se o número de mercadorias produzidas por período de trabalho, o que diminui o valor individual de cada uma delas. Com mercadorias mais baratas, o valor dos meios de subsistência (ou da força de trabalho) do trabalhador se torna, também, menor. O aumento intensivo da produtividade do capital tem, pois, como consequência, a diminuição do valor da força de trabalho e uma maior extração de mais-valor em um mesmo processo de trabalho. É esta a lógica formal com que Marx explica o impulso radical que o capital dá ao desenvolvimento técnico, científico e material das forças produtivas:

Para aumentar a produtividade do trabalho, reduzir o valor da força de trabalho por meio da elevação da força produtiva do trabalho e, assim, encurtar parte da jornada de trabalho necessária para a reprodução desse valor, ele tem de revolucionar as condições técnicas e sociais do processo de trabalho, portanto, revolucionar o próprio modo de produção. (MARX, 2013, p. 390)

Três são as formas de aumento intensivo da produtividade para obtenção de mais-valor relativo analisadas por Marx: a cooperação, a manufatura e, finalmente, a maquinaria e a grande indústria. Esta última é de especial importância para a perspectiva ecológica, pois representa a transformação qualitativa na qual o capital, agora a forma produtiva dominante, incorpora cada vez mais as forças produtivas da sociedade e da natureza em seu próprio movimento:

o capital, ao incorporar os dois formadores originais da riqueza, a força de trabalho e a terra, adquire uma força expansiva que lhe permite estender os elementos de sua acumulação além dos limites aparentemente fixados por sua própria grandeza, limites estabelecidos pelo valor e pela massa dos meios de produção já produzidos, nos quais o capital tem sua existência. (MARX, 2013, p. 679)

Forças naturais mecanicamente organizadas segundo um plano científico-capitalista - daí o salto verificado também nas ciências ditas naturais, que acompanharam em recíproco condicionamento o desenvolvimento técnico dos últimos séculos - substituem progressivamente o próprio ser humano no processo de trabalho, em um movimento que György Márkus (2015, pp. 83-85) chamou de desantropomorfização do trabalho sob a forma capitalista. Marx dá a este processo uma feição monstruosa, posto que demarca o surgimento de um aparato tecnológico - em que o elemento humano devém mero apêndice - cuja finalidade primordial é sugar mais-trabalho dos humanos (tendo como condição a apropriação de massas crescentes de matéria natural) que o operam:

Como sistema articulado de máquinas de trabalho movidas por um autômato central através de uma maquinaria de transmissão, a produção mecanizada atinge sua forma mais desenvolvida. No lugar da máquina isolada surge, aqui, um monstro mecânico cujo corpo ocupa fábricas inteiras e cuja forma demoníaca, inicialmente escondida sob o movimento quase solenemente mecânico de seus membros gigantescos, irrompe no turbilhão furioso e febril de seus incontáveis órgãos de trabalho propriamente ditos. (MARX, 2013, p. 455)

O aumento explosivo e devastador das forças produtivas nos últimos séculos, criador dos monstros técnicos do Antropoceno responsáveis pela reformatação da superfície planetária à imagem e semelhança do capital, tem, para Marx, como dúplice consequência (i) o arrasamento da fertilidade do solo 
e (ii) das capacidades físicas e mentais dos seres humanos, ambos submetidos ao autômato demoníaco do capital. Trata-se da mesma lógica predatória e arrasadora de suas bases naturais (humanas ou nãohumanas) que caracteriza o processo de produção capitalista e o impulsionamento das forças produtivas por ele efetivado. Nas palavras de Marx,

quanto mais um país, como os Estados Unidos da América do Norte, tem na grande indústria o ponto de partida de seu desenvolvimento, tanto mais rápido se mostra esse processo de destruição. Por isso, a produção capitalista só desenvolve a técnica e a combinação do processo de produção social na medida em que solapa os mananciais de toda a riqueza: a terra e o trabalhador. (MARX, 2013, pp. 573-574)

O incremento irrazoável das forças produtivas está na raiz da forma clássica de crise do capital, a crise de superprodução. A tendência a produzir quantidades cada vez maiores de mercadorias para diminuir seu valor e aumentar a taxa de exploração do mais-valor relativo significa que a produção capitalista de mercadorias não produz segundo as leis de oferta e demanda, mas sim conforme a sua própria tendência ao rebaixamento relativo do valor da força de trabalho, tendência inscrita na medula da produção. Não há mão invisível do mercado ou leis da circulação que possam, para Marx, harmonizar esse fato:

O volume das massas de mercadorias criadas pela produção capitalista é determinado pela escala dessa produção e pela necessidade de sua constante expansão, e não por um círculo predestinado de oferta e demanda, de necessidades a serem satisfeitas. (MARX, 2014, p. 155)

Se a "autoconservação do capital é sua autovalorização" (MARX, 2011, p. 254), então o capital, ao dar a própria medida "infinita" de sua produtividade, assim como da quantidade de input e output material que é incorporada em seus processos, alcança e devora parcelas maiores e maiores dos habitantes do planeta Terra no mesmo ritmo em que se autodestrói e se autorreconstrói a partir das crises que ele mesmo gera ${ }^{10}$.

É sabido que a intensificação do processo de urbanização anda de mãos atadas com o desenvolvimento técnico impulsionado pelo capital, tendo em vista a produção de um excesso populacional absoluto e relativo, que progressivamente tende a se organizar nos centros produtivos e financeiros que chamamos de cidades. Absoluto na medida em que o aumento da produtividade permite um incremento da quantidade absoluta de pessoas, de servos voluntários ou involuntários do capital, que podem viver simultaneamente. E relativo porque a substituição da força de trabalho mecânica pela humana gera o que Marx designou como exército industrial de reserva, um contingente de trabalhadores ora ocupados, ora sem emprego, constantemente ameaçados pela miséria por estarem à mercê dos movimentos de reestruturação produtiva dos diversos ramos do capital:

Quanto maiores forem a riqueza social, o capital em funcionamento, o volume e o vigor de seu crescimento e, portanto, também a grandeza absoluta do proletariado e a força produtiva de seu trabalho, tanto maior será o exército industrial de reserva. A força de trabalho disponível se desenvolve pelas mesmas causas que a força expansiva do capital. A grandeza proporcional do exército industrial de reserva acompanha, pois, o aumento das potências da riqueza. Mas quanto maior for esse exército de reserva em relação ao exército ativo de trabalhadores, tanto maior será a massa da superpopulação consolidada, cuja miséria está na razão inversa do martírio de seu trabalho. Por fim, quanto maior forem as camadas lazarentas da classe trabalhadora e o exército industrial 
de reserva, tanto maior será o pauperismo oficial. Essa é a lei geral, absoluta, da acumulação capitalista (MARX, 2013, pp. 719-720).

Ou seja, Marx descreve um modo de produção que produz aumento absoluto das riquezas para uma parcela da população (a classe dos capitalistas), aumento absoluto e relativo da população global trabalhadora e, por fim, aumento absoluto (nas periferias) e relativo (no centro) da pobreza desta população, sob o preço da devastação das forças humanas e, também, naturais:

O desenvolvimento da civilização e da indústria em geral mostrou-se sempre tão enérgico na destruição de florestas que tudo o que esse mesmo desenvolvimento tem feito para a conservação e a produção de árvores é absolutamente insignificante. (MARX, 2014, p. 338)

Em outro sentido, ressaltando ainda as contradições próprias à produção capitalista, surge da explosão de produtividade mais uma aporia no que Marx chama, no livro III, de composição orgânica do capital, isto é, a proporção de valor entre o capital constante (os meios de produção, as matérias-primas etc., que transferem um valor constante ao produto na medida de seu desgaste natural no processo de trabalho) e o capital variável (a própria força de trabalho, que cria intensiva e extensivamente quantidades variadas de valor no metabolismo natural com os meios de produção). Ora, se o mais-valor (e, por conseguinte, a sua expressão na forma-dinheiro, o lucro) é fruto do intercâmbio material da força de trabalho com os meios de produção e com as matérias primas, isso significa que a taxa de lucro será ditada pela composição orgânica do capital. Quanto maior a parcela do capital variável, da força de trabalho, na composição orgânica de capital, maior a taxa de lucro; inversamente, quanto maior a proporção do capital constante, menor a taxa de lucro. Foi mostrado acima, porém, que o aumento da produtividade do capital representa uma progressiva substituição, no processo de trabalho, da força humana de trabalho (que não é, contudo, jamais eliminada) pelas monstruosas máquinas da revolução industrial, que produzem incontavelmente mais e propiciam, ao capitalista, enormes quantidades de mais-valor relativo. Essa tendência contraditória (aumento da produtividade, alteração da composição orgânica, diminuição da taxa de lucro do capital) é expressa por Marx no livro III com a lei da queda tendencial da taxa de lucro (cf. MARX, 2017b, seção III), que constituiu “o mistério de toda a economia política desde Adam Smith":

Assim como a massa do trabalho vivo empregado sempre decresce em relação à massa do trabalho objetivado que o trabalho vivo mobiliza, isto é, em relação aos meios de produção produtivamente consumidos, também a parte desse trabalho vivo que não é paga e que se objetiva em mais-valor tem de encontrar-se numa proporção sempre decrescente em relação ao volume de valor do capital total empregado. E essa proporção entre a massa de mais-valor e o valor do capital total empregado constitui a taxa de lucro, que tem, portanto, de diminuir constantemente. (MARX, 2017b, p. 251)

Nada mais absurdo do que a loucura da produção capitalista, que produz um aumento absoluto da massa de lucro cujo correlato, porém, é a tendência estrutural à queda da taxa de lucro. Luiz Marques enuncia muito bem os perigos inerentes a uma queda tendencial da taxa de lucro, que se traduz, na medida do esgotamento dos recursos prontamente disponíveis, posto que já incorporados ao capital sob a forma de capital constante ou rejeitados como mero suporte material de um valor já realizado, em relações com o ambiente sucessivamente mais catastróficas. Como corolário da lei da queda tendencial da taxa de lucro, 
poder-se-ia falar, então, de uma lei da tendência estrutural do modo de produção capitalista ao esgotamento e à desorganização. Escreve Marques:

Eis a armadilha que enreda o sistema econômico global: quanto maior a escala de exploração de energia, minerais, solo, água, proteínas animais etc., mais escassos esses 'recursos' se tornam, mais poluente é sua exploração e mais intensa é a taxa de inovação tecnológica requerida para manter essa escala. Isso leva o sistema econômico a recorrer a atividades mais invasivas, custosas e destrutivas, o que, por sua vez, leva a economia a gerar mais alta entropia nela própria e no meio ambiente, desequilibrando os parâmetros biogeofísicos que prevaleceram no Holoceno. Surge, assim, no capitalismo global contemporâneo uma nova lei: a escassez ou maior poluição por abundância dos recursos naturais, as mudanças climáticas e demais equilíbrios ambientais serão doravante cada vez mais as variáveis decisivas na determinação da taxa de lucro do capital. (MARQUES, 2008, p. 64, cf. também cap. 13, item 13.3).

As tendências até aqui apresentadas ligam-se em especial à esfera da produção. Com relação à esfera da circulação de mercadorias (cuja importância para o movimento global do capital não é menor, pois é onde se adquirem os meios materiais que condicionam a sua existência - capital monetário - e onde se realiza o mais-valor nas mercadorias vendidas - capital mercadoria), as análises de Marx são igualmente importantes. De início, há a necessidade crescente, ditada pelos ritmos alucinógenos da produção, de meios de troca universais mais ágeis e velozes, pois quanto maior a rotação do capital (a quantidade de vezes em um determinado período que ele realiza suas três metamorfoses), maior é a taxa de mais-valor para o capitalista ( $c f$. 2014, seção II). As variegadas formas que o dinheiro assume encontram aqui sua causa, como já comentamos acima. Explica-se, com isso, a tendência global do capitalismo de tornar o tempo cada vez mais diluído e frágil, em que, nas palavras do Manifesto Comunista, "Tudo o que era sólido e estável se desmancha no ar" (MARX, ENGELS, 2008, p. 43).

Aparecem, então, os mais variados agentes sociais responsáveis por agenciar a circulação do capital, aqueles para quem o encanto de um dinheiro que se autovaloriza - sem mediações produtivas, que implicam necessariamente uma relação com o trabalho e com a natureza - é mais forte e difundido: os bancos e as instituições financeiras que regulam e distribuem os movimentos nacionais e internacionais de capital-monetário; os capitalistas comerciais, cuja função específica é a de facilitar a realização do capitalmercadoria; os rentistas que parasitam os ganhos da própria classe capitalista, da mesma forma que esta parasita o restante do mundo etc. Com estas subclasses do conjunto maior dos capitalistas, a ilusão de um crescimento descolado de quaisquer limites naturais finalmente alcança sua máxima potência: como consequência do encanto da forma-dinheiro, os meios de circulação, que apenas facilitam o movimento geral do capital, assumem formas cada vez mais fetichizadas ao se crer que são capazes de gerar por si só valor (o complexo dos ciclos de produção e circulação do capital é transmutado na fórmula mágica D-D', dinheiro que se autovaloriza sem mediações naturais ou sociais). Escreve, desta perspectiva, Marx:

o tempo de curso do capital limita, em geral seu tempo de produção, e, por conseguinte, seu processo de valorização. E os limita, decerto, em relação à sua duração. (...) Mas o que a economia política vê é a aparência, a saber, o efeito que o tempo de circulação exerce sobre o processo de valorização do capital em geral. Ela toma esse efeito negativo como positivo, porque suas consequências são positivas. Ela se agarra tanto mais a essa aparência porque crê encontrar a prova de que o capital contém em si uma fonte mística de autovalorização, que flui na esfera da circulação, 
independentemente de seu processo de produção e, portanto, da exploração do trabalho. (MARX, 2014, p. 205)

Uma tal complexidade e especificidade sumamente contraditória da maneira como se regula o metabolismo com a natureza a partir de fins determinados pelo acúmulo de valor (em outros termos: de como funciona o processo de global de circulação e produção capitalista, que não visa senão o acúmulo de valor sob sua forma fetichizada, o dinheiro) é, para Marx, um signo maior do caráter histórico desta produção. Logo, contra o imaginário encantado de uma naturalidade teleológica na qual todas as sociedades seriam protocapitalistas ou tenderiam ao modo de produção capitalista, Marx não apenas aponta a gênese material-social destas ilusões, mas também reafirma seu caráter histórico e, por isso mesmo, transitório. Nesse sentido, ele explica que:

a natureza não produz possuidores de dinheiro e de mercadorias, de um lado, e simples possuidores de suas próprias forças de trabalho, de outro. Essa não é uma relação histórico-natural, tampouco uma relação social comum a todos os períodos históricos, mas é claramente o resultado de um desenvolvimento histórico anterior, o produto de muitas revoluções econômicas, da destruição de toda uma série de formas anteriores de produção social. (MARX, 2013, p. 244)

Esta destruição é especialmente evidente quando Marx fala dos diversos momentos do que ele chama de acumulação originária ou primitiva, que, na condição de "pré-história do capital", "desempenha na economia política aproximadamente o mesmo papel do pecado original na teologia” (MARX, 2013, pp. 784-785). A acumulação originária descreve os momentos essenciais nos quais o capital realizou, à força e seu grande cúmplice, aqui, é a violência do Estado burguês - seja uma obtenção de valor, seja um estabelecimento de condições materiais, que possibilitaram o início dos ciclos infernais da reprodução ampliada ou da acumulação de valor. Nestes processos históricos,

como se sabe, o papel principal é desempenhado pela conquista, a subjugação, o assassínio para roubar, em suma, a violência. Já na economia política, tão branda, imperou sempre o idílio. Direito e 'trabalho' foram, desde tempos imemoriais, os únicos meios de enriquecimento, excetuando-se sempre, é claro, 'este ano'. $\mathrm{Na}$ realidade, os métodos da acumulação primitiva podem ser qualquer coisa, menos idílicos (MARX, 2013, p. 786).

Mencionemos sumariamente alguns de seus momentos fundamentais, de uma perspectiva ecológica. A expropriação dos trabalhadores rurais de seus meios de produção através da ação violenta do Estado, camponeses que tinham seus modos de vida intimamente ligados aos ritmos da terra e à produção voltada para valores de uso, contribui triplamente para o surgimento do modo de produção capitalista, ao fornecer contingente populacional para o nascente proletariado urbano, e também terra e capital inicial para os capitalistas que os expropriaram. Marx cita, ao final deste argumento, as seguintes palavras de Robert Somers a respeito do processo de expropriação na Escócia:

E a opressão cresce ainda diariamente. Clareamento e expulsão do povo são seguidos pelos proprietários como princípios inexoráveis, como uma necessidade agrícola, do mesmo modo como são varridos as árvores e os arbustos nas florestas da América e da Austrália, e a operação segue sua marcha tranquila, adequada aos negócios. (SOMERS apud MARX, 2013, p. 804) 
Outro momento essencial é a criação, através dos séculos de espoliação capitalista nas colônias, do mercado mundial, que expressa a culminância do modo de produção capitalista. Não apenas isto, pois as próprias colônias - e os fluxos diretos ou indiretos de ouro, prata, especiarias, matérias-primas e trabalho - foram condições imprescindíveis para o surgimento do capitalismo industrial global:

A descoberta das terras auríferas e a argentíferas na América, o extermínio, a escravização e o soterramento da população nativa nas minas, o começo da conquista e saqueio das Índias Orientais, a transformação da África numa reserva para a caça comercial de peles-negras caracterizam a aurora da era da produção capitalista. Esses processos idílicos constituem momentos fundamentais da acumulação primitiva. A eles se segue imediatamente a guerra comercial entre as nações europeias, tendo o globo terrestre como palco. (...) Tais métodos, como, por exemplo, o sistema colonial, baseiam-se, em parte, na violência mais brutal. Todos eles, porém, lançaram mão do poder do Estado, da violência concentrada e organizada da sociedade, para impulsionar artificialmente o processo de transformação do modo de produção feudal em capitalista e abreviar a transição de um para o outro. (MARX, 2013, p. 821)

\section{A renda da terra e a ruptura metabólica através da acumulação do capital}

Uma análise panorâmica dos movimentos mais gerais do modo de produção capitalista tal como descritos por Marx nos três livros de $O$ capital resulta, como apresentado até agora, no papel sistêmico atribuído às relações com a natureza no projeto da crítica da economia política. Uma natureza que se mostra tão devastada quanto os trabalhadores, vitimados por séculos de exploração capitalista, desponta das páginas destes livros. Vemos também um esforço conceitual de Marx que pretende dar conta das diversas formas pelas quais o capital empreende suas operações simultâneas de fetichização, ocultamento e aparência de naturalidade, ao descolar, através de sua forma, a finalidade da produção dos conteúdos materiais, naturais e sociais que a realizam em prol do regime abstrato de acumulação de valor. Uma transformação, ainda, salta aos olhos. As menções ao crescimento indefinido das forças produtivas como causa, instrumento e objetivo da revolução da classe trabalhadora (a exemplo do Manifesto Comunista e dos Grundrisse, citados em nota acima) são substituídas por Marx em O capital por uma análise que assimila - e as muitíssimas analogias entre exploração da natureza e exploração dos seres humanos que expusemos acima não são, nesse sentido, acidentais - a uma mesma "lógica da desagregação" (ADORNO, 2009, p. 127) a devastação do planeta e a destruição do ser humano, cuja causa comum é, evidentemente, a acumulação fetichista de capital, que "nasce escorrendo sangue e lama por todos os poros, da cabeça aos pés” (MARX, 2013, p. 830)

A causa desta inflexão marxiana, a partir da década de 60 , em direção a questões e respostas que hoje caracterizamos como ecológica (do aumento revolucionário da produtividade à devastação social e natural pela acumulação técnico-fetichizada do capital), se dá pelo encontro de Marx com a obra do químico agrícola alemão Justus von Liebig, um encontro que ocorre em meio aos intensos estudos que Marx realizava acerca da renda da terra, tendo passado por grande parte do material científico e econômico sobre o tema disponível à época - seus cadernos de extratos, hoje publicados na MEGA-2, mostram a abrangência de seus estudos ${ }^{11}$. 
Liebig publicou em 1840 o influente livro Die organische Chemie in ibrer Annvendung auf Agricultur und Physiologie [A química orgânica em sua aplicação à agricultura e fisiologia], que repercutiu enormemente, tanto pelo rigor científico como pela abrangência explicativa, sobre os debates em torno da fertilidade do solo, tornando seu autor uma das grandes referências internacionais no assunto. Liebig teve sua pesquisa comissionada em 1837, no contexto das grandes crises agrícolas que afligiam a Europa e a América do Norte, os dois maiores polos da agricultura capitalista-industrial no período; sua investigação, de início, mostrou a possibilidade cientificamente orientada de um aumento, através de componentes orgânicos e inorgânicos, da rentabilidade do solo e da vida das plantas. Mas o químico alemão não manteve sua visão estática: nas sucessivas reedições de sua obra, o direcionamento às questões ambientais e à crítica às formas organizativas de produção capitalista, em especial quando se tratava das relações com o solo e da crescente divisão entre cidade e campo, tornou-se cada vez mais forte. Dessa forma, Liebig, durante seus estudos, confirmou e passou a ser um dos grandes defensores da chamada lei dos rendimentos decrescentes, uma lei cujo conteúdo enuncia que, a partir de um dado estágio de consumo dos recursos naturais, a despeito de quaisquer quantidades de fertilizantes e trabalho adicionados ao solo, sua rentabilidade tende à diminuição.

Ainda que Marx critique, em uma nota de O capital, Liebig por creditar à John Stuart Mill a lei dos rendimentos decrescentes e por sua compreensão não tão acurada da economia política, o valor científico de suas investigações permanece fundacional para o conjunto teórico da crítica da economia política (MARX, 2013, pp. 573-574, n325). Tanto é que as mudanças que Liebig operou em sua obra no que tange à problemática do esgotamento do solo são, nas suas linhas gerais, acompanhadas por Marx: na década de 40, predominavam em Liebig as asserções sobre um aumento cientificamente orientado da produtividade do solo a partir do uso de componentes específicos; na década de 50 e 60 , por sua vez, o motivo principal já eram as considerações sobre uma tendência ao esgotamento dos recursos apesar do trabalho e da técnica. Marx, na mesma nota, refere-se a Liebig nos seguintes termos: "Ter analisado o aspecto negativo da agricultura moderna de um ponto de vista científico é um dos méritos imortais de Liebig" (MARX, 2013, pp. 573-574, n325).

Acima atestamos a maneira pela qual Marx, numa acepção abstrata, isto é, que desconsidera as formas sociais específicas que revestem essa relação, define o trabalho criador de valores de uso como uma "condição de existência do homem, independente de todas as formas sociais, eterna necessidade natural de mediação do metabolismo entre homem e natureza e, portanto, da vida humana" (MARX, 2013, p. 120). O trabalho, enquanto peça central do edifício da crítica da economia política, situa no cerne do pensamento exposto em $O$ capital as constelações entre, no geral, as diversas sociedades humanas e a natureza e, em particular, a maneira como o modo de produção capitalista regula seu metabolismo com a natureza a partir das tendências concretas e estruturais oriundas das relações que são estabelecidas entre forças produtivas e relações de produção. As diversas menções que Marx faz à ação predatória do capital sobre a natureza e sobre os seres humanos são vinculadas à mesma lógica destrutiva e sistêmica da acumulação. Mas o livro III, cujos manuscritos no geral antecedem àqueles publicados postumamente no 
livro II e em vida no livro I, oferece uma conceitualização propriamente dita das repercussões do modo de produção capitalista sobre o metabolismo social com a natureza, teorização que é elaborada mediante a integração dos resultados da química orgânica de Liebig à analítica do movimento produtivo do capital empreendida por Marx na década de 60, em especial a partir de 1863. Se este é o caso, as teorizações do livro III já estão, ao menos, no plano de fundo explorado pelo livro I, donde o caráter sistematicamente recorrente das "analogias" e conexões entre exploração humana e exploração da natureza.

Esta integração acontece, mais uma vez, na discussão sobre os rendimentos do solo no livro III de $O$ capital (2017b, seção VI). Nestas páginas, a teoria sobre a renda fundiária recebe uma redação muito mais sofisticada (se comparada às anteriores elaboradas por Marx), encabeçada por cálculos e tabelas e pela categoria da renda diferencial, que busca investigar como diferentes solos, a partir de suas qualidades naturais e investimentos sociais de capital, geram mais ou menos renda (isto é, abocanham uma parcela do mais-valor total produzido em uma sociedade dada) ao proprietário fundiário ${ }^{12}$. Marx desdobra a análise da renda diferencial em diferentes fertilidades do solo, relacionadas tanto à sua composição orgânica e inorgânica quanto às forças produtivas sociais nelas aplicadas: são detalhados, assim, os casos em que a rentabilidade aumenta, decresce e permanece constante ou, ainda, em que "massas de capital de produtividade diversa [são] investidas sucessivamente num mesmo terreno ou lado a lado em dois terrenos" (MARX, 2017b, p. 738).

Vemos, assim, em muitas passagens desta seção como a articulação conceitual entre qualidades naturais e propriedades advindas do investimento técnico-científico no movimento maior de produção do capital funda a análise da renda em suas variadas formas (diferencial I, diferencial II, absoluta, de terrenos para construção, de mineração etc.). Mas ao examinar a renda diferencial no pior solo, a recomendação de Marx, quando se trata da lei dos retornos decrescentes, é clara: "Acerca da produtividade decrescente do solo em investimentos sucessivos de capital, o leitor deve consultar Liebig" (MARX, 2017b, p. 805). E o que diferencia o melhor solo dos piores, para além dos investimentos de capital nele realizados, são suas qualidades naturais que, sob o regime da propriedade privada (lembremos da citada em nota definição abstrata de propriedade como atitude em relação às condições naturais de objetivação do trabalho), não apenas garantem, pela violência do Estado, ao proprietário fundiário “o poder de usar e abusar de porções do planeta" (MARX, 2017b, p. 677), mas sobretudo servem como causa para que ele abocanhe um lucro extra do total realizado pelo capital em um determinado período:

Onde quer que forças naturais possam ser monopolizadas e proporcionem um lucro extra ao industrial que as explora, seja uma queda d'água, uma mina rica, águas com abundâncias de peixes, seja um terreno para construção bem localizado, a pessoa cujo título sobre uma parte do globo terrestre a caracteriza como proprietária desses objetos naturais subtrai esse lucro extra, na forma de renda, ao capital em funcionamento. (MARX, 2017b, p. 833)

Marx não hesita em retirar da charneira jurídico-capitalista denominada "propriedade privada" consequências nefastas para a própria habitabilidade da vida no globo terrestre, consequências que ressoam ainda hoje com uma radicalidade ecológica e social imensa, porquanto dimensionam a acumulação capitalista nos termos catastróficos que dela decorrem: 
Uma parte da sociedade [os proprietários fundiários] exige da outra [os trabalhadores em luta pelo salário] um tributo em troca do direito de habitar a Terra, assim como, de modo geral, a propriedade fundiária implica o direito dos proprietários a explorar o corpo do planeta, as entranhas da Terra, a atmosfera e, com isso, a conservação e o desenvolvimento da vida (MARX, 2017b, p. 834).

Numa contraposição radical à vocação extrativa e extintiva do capitalismo, em um dos poucos momentos em que se refere, em $O$ capital, à maneira como uma sociedade futura de trabalhadores associados organizaria sua produção (em outras palavras: regularia seu metabolismo social com a natureza), projeta Marx:

Do ponto de vista de uma formação econômica superior da sociedade, a propriedade privada do globo terrestre nas mãos de indivíduos isolados parecerá tão absurda quanto a propriedade privada de um ser humano sobre outro ser humano. Mesmo uma sociedade inteira, uma nação, ou, mais ainda, todas as sociedades contemporâneas reunidas não são proprietárias da Terra. São apenas possuidoras, usufrutuárias dela, e, como boni patres famílias, devem legá-la melhorada às gerações seguintes (MARX, 2017b, p. 836).

Marx não se atém a um mero princípio da responsabilidade de gerações não mais acorrentadas pelo regime da propriedade privada em relação aos seus descendentes vindouros. Mais ainda, ele proclama um dever ativo de melhoramento - que certamente passaria por um redimensionamento qualitativo e por um apagamento das tendências produtivistas da técnica e da ciência, produzidas em uma nova forma social que não às submeta ao fetiche da acumulação ${ }^{13}$ - da Terra como legado maior, na sociedade comunista, do presente ao futuro.

O contraponto capitalista à visão comunista esboçada por Marx é funesto, um contraponto que vemos hoje catastroficamente se desenrolar a todo vapor. As últimas páginas do capítulo 47 do livro III fecham a seção VI, sobre a renda da terra, com uma discussão sobre o que chamo de teoria marxiana do colapso ambiental. O conceito de Marx que dá conta deste processo é denominado ruptura metabólica (Riß des Stoffwechsels); ele indica o momento em que a regulação do metabolismo (ou intercâmbio material) da sociedade com a natureza é rompido de maneira irreversível pela conjunção capitalista da separação entre cidade e campo, do crescimento exponencial das forças produtivas e do uso irracional do solo em benefício de uma minoria. Marx argumenta que, tanto no caso da pequena propriedade, em razão da falta de conhecimentos científicos e de meios técnicos, como no caso da grande propriedade, que mobiliza a exploração humana e natural em função do fetichizado enriquecimento de uma minoria apropriadora,

o cultivo racional e consciente do solo como propriedade perene da comunidade, condição inalienável da existência e da reprodução das gerações humanas que se substituem umas às outras, cedem lugar à exploração e o desperdício das forças da terra. (MARX, 2017b, p. 872)

Sobretudo a última forma de propriedade da terra, a grande propriedade fundiária, comporta um perigo iníquo para a vida humana presente e futura, o perigo da ruptura metabólica. Marx refere-se a ela nos seguintes termos:

a grande propriedade do solo reduz a população agrícola a um mínimo em diminuição constante e opõe-lhe uma população industrial cada vez maior, aglomerada em grandes cidades, gerando assim as condições para uma ruptura irremediável no metabolismo social, prescrito pelas leis naturais da vida; dessa ruptura decorre o desperdício da força 
da terra, o qual, em virtude do comércio, é levado muito além das fronteiras do próprio país. (Liebig.) (MARX, 2017b, p. 873)

Este trecho é notável, para além da sua menção final à Leibig, por diversas razões. Em primeiro lugar, ele considera a conexão íntima entre a constituição da urbanização industrial proletária, de um lado, e a da agricultura industrial capitalista, de outro, através de sua mútua intensificação e destrutividade. Tanto é que, na sequência imediata desta passagem citada, é possível ler que:

Se num primeiro momento elas se distinguem pelo fato de que a primeira devasta e destrói mais a força de trabalho e, com isso, a força natural do homem, ao passo que a segunda depreda mais diretamente a força natural da terra, posteriormente, no curso do desenvolvimento, ambas se dão as mãos, uma vez que o sistema industrial na zona rural também exaure os trabalhadores, enquanto a indústria e o comércio, por sua vez, fornecem à agricultura os meios para o esgotamento do solo. (MARX, 2017b, p. 873)

O pontapé inicial deste processo é o momento primordial da acumulação originária, a expropriação dos camponeses de seus meios de produção no batismo de sangue do capitalismo nascente, o seu motor de continuidade são as metamorfoses do capital na busca perpétua do mais-valor. Em segundo lugar, este trecho ressalta, mais uma vez, a importância do intercâmbio material com a natureza como a base fundamental de toda a produção material-social humana, e a sua necessária regulação a partir de parâmetros mais racionais sob o fáustico preço a ser pago, em caso contrário, de uma irreversível ruptura no metabolismo social-natural, ruptura operada pelo capitalismo nas próprias leis e ciclos da natureza. Finalmente, ele focaliza a dimensão global do problema, pois, em um mundo globalizado pelas aventuras coloniais e imperialistas do comércio capitalista, uma tal ruptura é transmitida em cadeia através das diversas mediações internacionais da produção e dos ciclos biogeofísicos do planeta.

Um trecho, enfim, que descreve perfeitamente algumas das ameaças cruciais que o modo de produção capitalista coloca às sociedades humanas organizadas e à vida como um todo no planeta Terra. Se lido à luz das outras tendências estruturais que o modo de produção capitalista carrega dentro de si (aumento das forças produtivas e da exploração do trabalho, queda tendencial da taxa de lucro, dissolução do espaço e do tempo, crescente descolamento do imaginário social de sua base natural-material através do fetichismo da mercadoria etc.), ele, quase como uma conclusão ao livro III de O capital - uma totalidade inacabada que, nas palavras de Adorno (2009, p. 295), vai “desde a análise da forma da mercadoria até a teoria do colapso em uma fenomenologia do antiespírito" - enseja a possibilidade de inteligibilização das crises sistêmicas criadas pelo capitalismo a partir de uma perspectiva ao mesmo tempo econômico-filosófica, histórico-natural e crítico-revolucionária. Foram as linhas gerais desse movimento que este artigo objetivou percorrer.

\section{Referências:}

ADORNO, T. Dialética Negativa. Rio de Janeiro: Jorge Zahar Editor Ltda, 2009.

BURKETT, P. Marx and Nature: a Red and Green Perspective. New York: St. Martin's Press, 1999. FOSTER, J. B. Marx's Ecology: Materialism and Nature. New York: Monthly Review Press, 2000. 
GEORGESCU-ROEGEN, N. Energy and Economy Myths. Southern Economic Journal, v. 41, n. 3, pp. 347-381, 1975.

LÖWY, M. O que é ecossocialismo? São Paulo: Cortez, 2014.

MÁRKUS, G. Marxismo e antropologia: o conceito de 'essência humana' na filosofia de Marx. São Paulo: Expressão Popular, 2015.

MARQUES, L. Capitalismo e colapso ambiental. $3^{a}$ edição revista. Campinas: Editora da Unicamp, 2018.

MARX, K. Grundrisse: manuscritos econômicos de 1857-1858. Esboços da crítica da economia política. São Paulo: Boitempo; Rio de Janeiro: Ed. UFRJ, 2011.

MARX, K. Miséria da filosofia. São Paulo: Boitempo, 2017a.

MARX, K. O capital: crítica da economia política. Livro I: o processo de produção do capital. São Paulo: Boitempo, 2013.

MARX, K. O capital: crítica da economia política. Livro II: o processo de circulação do capital. Edição de Friedrich Engels. São Paulo: Boitempo, 2014.

MARX, K. O capital: crítica da economia política. Livro III: o processo global de produção capitalista. Edição de Friedrich Engels. São Paulo: Boitempo, 2017b.

MARX, K; ENGELS, F. A ideologia alemã. São Paulo: Boitempo, 2007.

MARX, K; ENGELS, F. Manifesto Comunista. 1ª ed. revista. São Paulo: Boitempo, 2010.

ROSDOLSKY, R. Gênese e estrutura de O capital de Marx. Rio de Janeiro: EDUERJ: Contraponto, 2001.

SAITO, K. Karl Marx's Ecosocialism - Capitalism, Nature and the Unfinished Critique of Political Economy. New York: Monthly Review Press, 2017.

SCHMIDT, A. The Concept of Nature in Marx. London, New York: Verso, 2014.

\footnotetext{
Notas

${ }^{1}$ Graduando em Filosofia pela Universidade Federal do Paraná. Membro Bolsista do PET-Filosofia UFPR. Membro Estudante do SPECIES - Núcleo de Antropologia Especulativa: dgp.cnpq.br/dgp/espelhogrupo/0895998730250355. Plataforma Lattes: http://lattes.cnpq.br/7312042936373163. Orcid: https://orcid.org/0000-0001-5567-7607. E-mail: gabrielprgioppo@gmail.com

2 De teóricos da relação entre economia e entropia, como Georgescu-Roegen (1975, pp. 348, 360) a comentadores de Marx como Michael Löwy (2014, pp. 21-38) e Alfred Schmidt (2014, cap. 4) e filósofos marxistas como Theodor Adorno (2009, pp. 205206), a orientação produtivista do pensamento marxiano é asseverada em diversos graus e sob diversas formas no pensamento crítico e/ou ecológico. Até mesmo Luiz Marques (2018, p. 39) reproduz essa imagem de maneira precisa, ao apontar em Marx, a despeito de certas intuições ecológicas encontráveis de modo fragmentário em seus textos, a existência de uma "espécie de Mecânica da história 'sem natureza"', típica do século XIX e por isso culpada pela inércia ecológica das esquerdas no presente.

3 Alguns dos elementos fundamentais para a compreensão desta problemática nas obras da década de 40, analisados exaustivamente nas obras citadas de Saito e Foster, são: o materialismo aleatório da filosofia da natureza de Epicuro e Lucrécio descritos por Marx em sua tese de doutorado; a alienação da natureza e o contraponto revolucionário de um comunismo simultaneamente naturalista e humanista dos Manuscritos de 1844; a fundação teórica do materialismo histórico em termos de uma concepção materialista da história e da natureza - dialeticamente imbricadas e codependentes - de $A$ ideologia alemãa a crítica ao Prometeu de Proudhon em $A$ miséria da filosofia (cf. MARX, 2000, pp. 92-93). Contudo, nas obras marxianas da década de 40 e 50 são perceptíveis, igualmente, elementos que contribuíram para a sua imagem "produtivista": os exemplos mais notáveis são certas declarações do Manifesto Comunista sobre a exigência conscientemente posta da revolução comunista de "aumentar o mais rapidamente possível o total das forças produtivas" (MARX, ENGELS, 2010, p. 49) ou, ainda, quando nos Grundrisse Marx (2011, p. 333-4) exalta a "exploração completa da Terra" realizada pelo capital como condição do "cultivo de todas as qualidades do ser humano social e sua produção como um ser, o mais rico possível em necessidades, porque rico em qualidades e relações", chegando ao ponto de mencionar uma "grande influência civilizatória do capital". Será explicitada no desenvolvimento da argumentação a razão pela qual Marx abandona essas posições "produtivistas" a partir da década de 60 , quando da elaboração de $O$ capital.
} 
${ }^{4}$ cf. Rosdolsky, 2001, cap. 2, para uma visão compreensiva das diversas formulações e mudanças de estrutura pelas quais passa o projeto marxiano de crítica da economia política até sua forma final, mas inacabada, de $O$ capital.

5 Antes da criação, nos anos 1860, do termo Oecologie por Ernst Haeckel, um autor também lido por Marx, a noção de "metabolismo" era a mais recorrente na literatura científica da época para descrever a economia da natureza ou, ainda, "o todo orgânico que consiste de plantas, animais e humanos" (SAITO, 2018, p. 47).

6 "Uma máquina que não serve no processo de trabalho é inútil. Além disso, ela se torna vítima das forças destruidoras do metabolismo natural. O ferro enferruja, a madeira apodrece. (...) O trabalho vivo tem de apoderar-se dessas coisas e despertá-las do mundo dos mortos, convertê-las de valores de uso apenas possíveis em valores de uso reais e efetivos." (MARX, 2013, p. 260).

${ }^{7} \mathrm{Na}$ seção dos Grundrisse intitulada "Formas que precedem a produção capitalista", Marx (2011, pp. 388-423) torna manifesta a predominância do caráter produtor de valores de uso nas formas sociais anteriores à capitalista, todas elas comunitárias e vinculadas à terra. Ou seja, toda propriedade - entendida aqui como "atitude do indivíduo em relação às condições naturais do trabalho e da reprodução como pertencendo a ele, como corpo objetivo, natureza inorgânica dada, de sua subjetividade" (MARX, 2011, p. 389) -, porque mediada pela comunidade, determina um processo de produção cuja finalidade é tão somente a reprodução da própria comunidade e de seus indivíduos (e não, como no modo de produção capitalista, o acúmulo de trabalho abstrato sob a forma da mercadoria-dinheiro) através da produção de valores de uso. Assim, destacando a excepcionalidade nas relações com a natureza que o regime de acumulação de capital, ao se apropriar da produção e estabelecer o trabalho assalariado, desapropriado de suas condições objetivas de efetivação, Marx (2011, p. 401) escreve que "Não é a unidade do ser humano vivo e ativo com as condições naturais, inorgânicas, do seu metabolismo com a natureza e, em consequência, a sua apropriação da natureza que precisa de explicação ou é resultado de um processo histórico, mas a separação entre essas condições inorgânicas da existência humana e essa existência ativa, uma separação que só está posta por completo na relação entre trabalho assalariado e capital".

${ }^{8}$ Foi precisamente essa uma das razões da ruptura de Marx e Engels com os Jovens Hegelianos em 1845-6, algo que fica explícito na longa polêmica de Marx contra Max Stirner em A ideologia alemã: cf. Marx, Engels, 2007, pp. 121-426.

9 Apesar da complexa gênese histórica do capitalismo, da multitude de fatores que exigiram seu funcionamento, uma vez estabelecidos, eles podem funcionar em quase qualquer situação produtiva que contenha trabalhadores expropriados de seus meios de produção e circulação de mercadorias e dinheiro, tendo seu limite virtual apenas na extinção generalizada: "o capital pode em princípio continuar a acumular sob quaisquer condições naturais, por mais degradadas que sejam, contanto que não haja uma extinção completa da vida humana” (BURKETT, 1999, p. 196).

10 Paul Burkett (1999, p. 108) destaca a relevância ecológica da tendência estrutural à crise de superprodução capitalista nos seguintes termos: "a tendência do capital para acelerar o output material para além de seus limites naturais não é apenas uma fonte de escassez material e crises de acumulação; é também um elemento integral no processo de degradação ecológica produzida pela divisão capitalista de cidade e campo".

11 Sobre a interpretação da seção sobre a renda da terra, do livro III de O capital, e da sua culminação, perspectivada ambientalmente, com a categoria de ruptura metabólica, segue-se neste as linhas gerais da argumentação de Foster (2000, cap. 5) e Saito (2017, caps. 3-5)

12 A importância da diversidade dos elementos naturais na formação da renda da terra é reiteradamente enfatizada por Marx. Ao comparar, por exemplo, a produtividade de dois terrenos em relação aos custos de produção médios de uma sociedade, um deles dotado de uma queda d'água monopolizável que aumentaria a produtividade e outro sem um semelhante equivalente natural, diz Marx que "essa renda, evidentemente, é sempre diferencial, pois não entra de maneira decisiva no preço de produção geral da mercadoria, mas o pressupõe. Ela deriva da diferença entre o preço de produção individual do capital individual, que tem à disposição a força natural monopolizada, e o preço de produção geral do capital investido nessa esfera de produção". Desse modo, "a propriedade da terra capacita o proprietário a apoderar-se da diferença entre o lucro individual e o lucro médio; o lucro assim embolsado, que se renova anualmente, pode ser capitalizado e aparece, então, como preço da própria força natural" (MARX, 2017b, 709-10).

${ }^{13}$ Sobre essa transformação quantitativa e qualitativa da técnica e das ciências naturais em um modelo de sociedade futura, a dos trabalhadores associados não mais acorrentados e sugados em suas forças vitais pela produção capitalista, $c f$. Burkett, 1999, cap. 14. 